namely : "An officer whose remuneration is fixed on the assumption that his whole time is at the disposal of the Government is prohibited from engaging in trade, or employing himself in any commercial or agricultural undertaking". While agreeing that it is undesirable for servants of Colonial Governments to act as consultants to industrial firms, the Joint Council expressed the view to the Colonial Office that it was not in the best interests of the Service for this rule to be interpreted in such a way that it would prevent a scientific worker acting, for example, as a university examiner or undertaking other academic work or contributing to scientific literature in the ordinary way. The Council's view was that much would be gained if scientific members of the staff of an establishment were free to undertake such extra-mural work as the director of research, or other responsible officer, expressly approved, and if these directors and officers had wide discretion in authorizing such work and in deciding what extra-mural activities they themselves should undertake. These views were submitted to the Colonial Office in a document signed by its chairman and the presidents of its four constituent bodies: the Institute of Biology, the Royal Institute of Chemistry, the Institution of Metallurgists and the Institute of Physics.

The Assistant Under-Secretary of State for the Colonies in charge of research, both in interview and in correspondence, pointed out that it is a matter of common practice for scientific officers in the service of Colonial Governments to contribute to scientific literature, and in the same way other officers frequently publish matters not excluded by the terms of the Colonial Regulation. He also pointed out that it is by no means uncommon for specialist officers employed by a Colonial Government to undertake, for remuneration, lectures at a university or college in the territory and to serve as external examiners. The official view is that in general the regulations are interpreted reasonably from the point of view of both scientific and other officers and of the Colonial Governments ; but the Secretary of State has undertaken to inquire into any particular case where it is considered that an unduly strict interpretation of the relevant Colonial regulations has been adopted.

\section{Co-operation between the Cape and Radcliffe Observatories}

All interested in astronomical observations will welcome the adoption of a scheme for co-operation between the British observatories in South Africa. By payment of an annual sum to the Radcliffe Trustees, the Cape Observatory will secure the use of the 74-in. reflector at Pretoria for a third of the observing time. As is well known, the funds available for the Radcliffe Observatory suffice for the employment of only three astronomers-not nearly enough to make full use of the telescope, which is the largest in the southern hemisphere. The additional sum made available will enable the observatory to engage a mechanic-night assistant and a secretary-librarian, and so take a burden off the scientific staff. What money is.left over will be used for improving the subsidiary equipment and buildings. At the same time, the Cape Observatory will be enabled to extend its researches ; for although it has many instruments, they have only moderate light grasp and most of them are fifty or more years old. The Cape Observatory has no reflecting telescope. For the last few years the Cape astronomers have had occasional use of the 74-in. reflector through the courtesy of the Radcliffe Observer, and they can appreciate the possibilities of the new arrangement. Astronomers are only too well aware of the exasperating delays which almost always take place between the planning of a telescope and bringing it into use, and the fact that the 74-in. reflector is already in operation is a point of no small importance.

\section{The Elliott Journal}

In 1800 William Elliott set up in business as a maker of scientific apparatus, and for a hundred and fifty years the firm, now Elliott Brothers (London), Ltd., has been associated with instrument making. It is appropriate that the achievements of this firm, its history and the work it is doing should be made known as widely as possible. We therefore welcome the first number of 'i he Elliott Journal, admittedly a house journal but one which will be read with interest by many not immediately associated with the firm. The Journal is to be published half-yearly and its aim is to give a periodical review of developments in engineering and physical science with particular reference to the work of Elliott Bros. The first number contains a brief foreword by Sir Ben Lockspeiser ; a summary of the history of the firm since its foundation; and eight illustrated articles. These discuss the following topies : magnetic amplifiers and their application to industrial purposes; pulsed circuits for resistance strain-gauges; application of the force-balance principle to pneumatic instruments for process control ; a photo-electric curve follower ; precision A.C. measurement with a D.C./A.C. comparator; a phase-front plotter for testing micro-wave aerials; a precision sine-cosine potentiometer; and thermal fluctuation of charge in linear circuits.

\section{Mycopathologia et Mycologia Applicata}

THE appearance of the first fascicule of Vol. 5 of the journal Mycopathologia under the enlarged title Mycopathologia et Mycologia Applicata indicates the wider range that has now been assumed by the journal with the inclusion of more general papers on applied mycology. As the former title suggests, Mycopathologia has for several years been the chief world repository for papers on medical mycology. The development of this subject must, indeed, have owed a good deal to the journal, for medical applications of mycology are now known in areas where human fungus diseases were largely unsuspected. Mycological pathology will, indeed, still be represented strongly. The present issue includes, inter alia, studies of antidotal properties of various fungi, against the staphylococcus toxin, by Anna Maria Villa; a detailed paper on vitamin deficiencies of pathogenic fungi, by A. E. de Arêa Leão and Amadeu Cury; a critical survey of mycological literature between 1939 and 1942 (Tibor Benedek); and a description of the fungistatic activities of vitamin $\mathrm{K}$ on dermatophytes, by A. E. Arêa Leão and Adolpho da Rocha Furtado. Typical of the wider scope is a paper on the enzymatic grouping of bacteria, by Costantino Gosini. Mycopathologia et Mycologia Applicata is published by Dr. W. Junk, of 13 Van Stolkweg, The Hague, Netherlands, and the present number is priced at 40 guilders, or $\mathfrak{1} 315 s .4 d$.

\section{Research in the University of Birmingham}

THE Joint Standing Committee for Research of the University of Birmingham has issued in its 